\title{
FARMER PERCEPTIONS OF BIRD DAMAGE AND CONTROL IN ARABLE CROPS
}

\author{
J.D. COLEMAN and E.B. SPURR
}

\author{
Landcare Research, P.O. Box 69, Lincoln 8152, New Zealand
}

Corresponding author: colemanj@landcare.cri.nz

\begin{abstract}
One hundred arable farmers from across New Zealand were randomly selected and interviewed in summer 2000, to assess their perceptions of the nature and extent of bird damage to their crops, the bird species involved, the factors affecting the level of damage, and the type and cost of any bird control undertaken. Most farmers considered birds caused serious damage to their crops, with wheat, barley, peas and some speciality seed crops, such as brassicas, borage and evening primrose, most at risk. Damage was rarely perceived to exceed $5 \%$ in cereals but was often higher in speciality crops. It was most severe at seed maturation. The birds responsible for most of the damage were house sparrows and greenfinches. Most farmers undertook some form of bird control to protect their crops, with shooting, gas guns and avicides most commonly used. The overall expenditure on bird control was far less than the value of the damage reported.

Keywords: arable crops, bird damage, bird control.
\end{abstract}

\section{INTRODUCTION}

Damage by birds is one of the greatest problems facing growers of a wide variety of arable crops in New Zealand. However, the amount of crop lost and the economic damage sustained is largely unquantified. Most farmers believe the losses to be significant, as they see many birds entering and leaving their crops, and regularly observe damage about the edge of crops. In consequence, many farmers attempt to reduce crop losses from birds by undertaking some form of bird control, with scaring devices and avicides (pesticides) most commonly used. This is possible because most damage by birds in arable crops stems from the feeding activities of introduced species, and the manipulation of their populations is lawful. However, many of the methods used are of questionable efficacy, some are poorly understood and applied, and most are expensive.

Our study sought to summarise the representative opinions of arable crop farmers in New Zealand on both the nature and extent of bird damage to their crops, and the type and cost of bird control. This information will be used to promote the better use of existing control methods and to provide direction for new research programmes aimed at the improved control of bird pests being developed by Landcare Research for initiation in 2001/02.

\section{METHODS}

We developed a questionnaire for use in a nation-wide survey of 100 arable farmers chosen by the Foundation for Arable Research (FAR) from their client base of 3200, approximately $50 \%$ of which farm in Canterbury. The farmers were selected randomly from grain/cereal growing areas of New Zealand but with the following proviso: $80 \%$ farmed 'large' properties and $20 \%$ farmed 'small' properties. Those surveyed largely resided in Canterbury (91), with most from the Ashburton-Rakaia-Leeston area. All prospective respondents were advised by letter of the nature and aims of the survey. Subsequently, 85 farmers were surveyed by telephone and 15 were surveyed in person. No bias was noted with either technique. At interview, each farmer was informed of the confidentiality of his/her reply, and then asked a series of identical questions. The 
interview normally lasted about 30 minutes. Each survey began with questions on farmer demography. The next questions sought to determine how farmers perceived current and past bird damage in their crops, the species of birds that caused it, the crops attacked and their stage of maturity, and what local factors influenced the level of damage recorded. Finally, we sought information on the type and cost of any bird control undertaken. The maximum margin of error of the survey was $\pm 10 \%$.

\section{RESULTS}

Eighty-seven of the 100 respondents reported that birds had damaged their crops in 1999/ 2000 sufficiently seriously that they considered birds a 'problem'. Of these respondents, 49 thought the damage minor and occasional, 16 minor and persistent, 15 major and occasional, and 6 major and persistent, while one respondent failed to answer the question. Thus, 76\% of the farmers reporting "significant" damage believed it to be only minor.

Twenty-four arable crops were thought likely to be damaged by birds, with most of the area of crop thought to be at risk ( $2512 \mathrm{ha} ; 77 \%$ ) comprising wheat (1256 ha), barley (746 ha) and peas (510 ha). These crops were grown on most farms $(85,72$ and 63 respectively), but the reported percentage of these crops at risk from damage by birds was wheat $28 \%$, barley $29 \%$ and peas $31 \%$. By comparison, many specialty crops grown over much smaller areas were thought proportionately more likely to be damaged by birds, because all the crop was considered at risk. Such crops include brassicas (broccoli, radish, cabbage, turnip and canola), evening primrose, chicory and Chinese mustard.

Bird damage was observed by farmers on 26 crop types in 1999/2000 (Table 1). The extent of damage reported varied between crops, with losses from most cereal and pea crops being $<5 \%$, and rarely exceeding $20 \%$. Damage was greater on some specialty seed crops, often averaging $>5 \%$, with borage, radish, evening primrose, turnip and spinach being particularly hard hit. However, levels of damage reported must be treated cautiously. Most respondents had problems providing estimates of the extent of damage observed in any crop, not least because most damage occurs about the periphery of fields close to bird harbourage where it is most easily observed.

TABLE 1: Crops types and their level of damage by birds in 1999/2000 reported by two or more respondents ${ }^{1}$.

\begin{tabular}{|c|c|c|c|c|}
\hline \multirow{2}{*}{ Crop } & \multirow{2}{*}{$\begin{array}{l}\text { Number of } \\
\text { respondents } \\
\text { reporting bird } \\
\text { damage }\end{array}$} & \multicolumn{3}{|c|}{ Level of damage } \\
\hline & & $<5 \%$ & $5-20 \%$ & $>20 \%$ \\
\hline Wheat & 71 & 45 & 25 & 1 \\
\hline Barley & 49 & 37 & 10 & 2 \\
\hline Peas & 40 & 30 & 10 & 0 \\
\hline Borage & 14 & 7 & 7 & 0 \\
\hline Oats & 11 & 5 & 4 & 2 \\
\hline Radish & 12 & 5 & 7 & 0 \\
\hline Pak choi & 11 & 7 & 4 & 0 \\
\hline Kale & 6 & 4 & 2 & 0 \\
\hline Evening primrose & 6 & 2 & 3 & 1 \\
\hline Turnips & 5 & 1 & 2 & 2 \\
\hline Grass seed & 4 & 3 & 1 & 0 \\
\hline Spinach & 3 & 1 & 2 & 0 \\
\hline Ryecorn & 2 & 1 & 1 & 0 \\
\hline Canola & 2 & 0 & 1 & 0 \\
\hline
\end{tabular}

${ }^{1} \mathrm{~A}$ further 12 crop types damaged by birds were reported by only one respondent. 
Sixty-six respondents reported damage by birds at either the sowing or emergence of their crops. Damage at sowing and emergence was similar, and was most commonly observed on peas (54\% of all farms growing peas), wheat $(31 \%)$ and barley $(28 \%)$. However, the primary damage reported to all crops was that suffered prior to harvesting when grains and seeds were maturing.

Of the birds damaging their crops, "sparrows", "sparrow-like" or "small brown birds", apparently house sparrows and greenfinches, were considered most harmful $(82 \%$ of respondents). Rock pigeons, greenfinches and ducks were reported to damage crops by $20-30 \%$ of respondents, pukeko by $7 \%$, Canada goose, spur-winged plover, skylark, chaffinch and blackbird by $2 \%$ or less, and all other bird species present were thought to be non-harmful. Damage by house sparrows occurred commonly in wheat and barley at maturity, and in many of the speciality seed crops, e.g. borage, pak choi and radish. Greenfinches, though less frequently reported, attacked the same crops at maturity, and we believe their broad similarity to 'sparrows' may have led to their under-reporting. Rock pigeons and ducks (principally mallards) were commonly observed after sowing in peas but rarely in other crops, and pukeko were occasionally observed in wheat and barley.

Two-thirds of all respondents reported the presence of hedgerows, isolated trees or barn complexes in close proximity $(<1 \mathrm{~km})$ to at-risk crops, all of which provided roosting, resting and nesting areas for foraging passerines — particularly house sparrows and greenfinches. Most respondents recognised the consequences to their crops of withinfarm bird harbourage, but argued they needed the shelter to farm successfully.

Sixty-seven of the respondents undertook some form of bird control, with the most common being shooting to scare (35), gas gun scarers (32) and avicides (24). Avian kites, repellent sprays, repellent seed treatments, scarecrows, flashing lights, netting, alarms and plastic tape were used by fewer respondents. Shooting was the method of choice against ducks, rock pigeons and pukeko, while gas guns, avicides and all less frequently used techniques were used against house sparrows and greenfinches. Eighty respondents reported the presence of harrier hawks as natural bird control agents, and 20 respondents occasionally sought to encourage harrier hawks on their property by leaving rabbit or possum carcasses around for them to feed on.

Opinion on the effectiveness of these techniques varied. Most were thought to be 'better than nothing', and even respondents reporting a low effectiveness in previous years continued to use the same techniques. Repellent sprays, netting and unique bird alarms were regarded as the most effective, but few respondents used them. A combination of techniques, such as shooting and gas guns, were thought to give good results, more rather than fewer scaring units were considered to improve the effectiveness of control, and frequent relocation of scaring devices was reported as important.

The cost of bird control undertaken by most respondents appeared to be extremely low, and bore little relation to the value of the crop reported lost. Of the techniques commonly used, costs associated with gas guns were highest ( $\$ 507 /$ farm), those with repellent sprays (\$241/farm) and avicides (\$80/farm) intermediate, while those associated with shooting and avian kites were very low $(\$ 53-\$ 68 /$ farm $)$. Costs for infrequently used control techniques varied from $\$ 4000$ to hire nets to protect an entire crop of broccoli seed, to near zero for home-made plastic tape.

\section{DISCUSSION}

This survey had an advantage over other similar surveys (e.g. Bull 1983) because responses were obtained from all the farmers selected. We believe the responses fairly reflect the nature of the bird problem in arable crops, particularly in mid-Canterbury. However, although most farmers reported bird damage to many of their crops, such opinions are unfortunately not supported by any quantitative data on the amount of crop lost or its economic value. Our data were clearly qualitative, and we therefore made no attempt to convert farmer estimates of percent crop yield loss to dollars. Our results are similar to an earlier study (Dawson 1970) who estimated that $2.6 \%$ to $8.4 \%$ of wheat on 
11 farms was lost to birds, assuming no compensatory growth. As damage in our study related mostly to mature crops, compensatory growth again appeared unlikely.

Our survey indicated that house sparrows and greenfinches, particularly, targeted cereal and speciality seed crops, both at sowing and emergence, and later during seed ripening. Damage is most severe on speciality seed crops where a disproportionately large edge effect in the small areas of crop grown and the higher economic value of the crop make losses to birds less sustainable. House sparrows and greenfinches were also identified as important pests of cereals grown in Hawke's Bay (MacMillan 1981), with damage by house sparrows most significant.

Most of our respondents attempted to reduce bird damage by a combination of control techniques and strategies, predominantly scaring devices placed in or about crops. Opinion on the effectiveness of such devices was variable, but most respondents agreed that when correctly located and operated, most reduced the damage by birds habituated to crops in protected fields. This solution is, however, short-lived; problem bird species either return as soon as the scaring device is removed, or they move to adjacent crops, thus often penalising nearby farmers who are not using such techniques at that time.

Shooting was commonly used to control ducks and rock pigeons and occasionally to control house sparrows and greenfinches. Shooting is used primarily as a scaring technique, and few birds are hit. However, some respondents shoot to kill ducks. Such shooting is illegal, and puts at risk the legal use of firearms to scare bird pests.

A range of avicides were used by our respondents, but only alpha-chloralose is registered with the Pesticides Board (as PESTOFF® treated grain) for that purpose. Other chemicals used as avicides included two organophosphate insecticides and a carbamate insecticide. Another carbamate insecticide was used by one farmer as a bird repellent seed treatment. The illegal (off-label) use of insecticides as avicides and bird 'repellents' probably reflects both the lack of information about the availability of the registered product, alpha-chloralose, and the effectiveness for these purposes of 'onhand' insecticides. Farmers rated the effectiveness of alpha-chloralose from below average to excellent. There is a need for better education about the use of alpha-chloralose and of the hazards and legal consequences to the arable cropping industry of using unregistered products.

\section{ACKNOWLEDGEMENTS}

This work was funded by the Foundation for Research, Science and Technology and the Foundation for Arable Research.

\section{REFERENCES}

Bull, P.C. 1983: The complexities of assessing bird damage. N.Z. J. Agric. 146(4): 50 . Dawson, D.G. 1970: Estimation of grain loss due to sparrows (Passer domesticus) in New Zealand. N.Z. J. Agric. Res. 13: 681-688.

MacMillan, B.W.H. 1981: Food of house sparrows and greenfinches in a mixed farming district, Hawke's Bay, New Zealand. N.Z. J. Zool. 13: 93-104. 